\title{
Human Rights Violations Perpetrated by State Agents in Military Occupations: Analysis of the Incursion of International Human Rights LaW to the Normative Territory of the Armed Conflicts
}

\author{
Violaciones de Derechos Humanos Perpetradas por Agentes del Estado en \\ Ocupaciones Militares: Análisis de la Incursión del Derecho Internacional \\ de los Derechos Humanos al Territorio Normativo de los Conflictos
}

\author{
Armados
}

\section{Violações de Direitos Humanos Perpetrados por Agentes Estatais em Ocupações Militares: Análise da Incursão do Direito Internacional dos Direitos Humanos ao Território Normativo dos Conflitos Armados}

\author{
Sidney Cesar Silva Guerra* \\ Luz E. Nagle \\ Ádria Saviano Fabricio da Silva
}

\begin{abstract}
* Post-Doctor from the Center for Social Studies (CES) - University of Coimbra; Visiting Researcher by Stetson University Law School. Post-Doctor in Culture by the Advanced Program of Contemporary Culture - Federal University of Rio de Janeiro (PACC/UFRJ); and Post-Doctor in Law - Universidade Presbiteriana Mackenzie (SP). He holds a Doctorate, Master and Specialization in Law. Full Professor at UFRJ and Permanent Professor of the Postgraduate Program in Human Rights (Doctorate and Master's) at the National Faculty of Law - Federal University of Rio de Janeiro (FND/UFRJ). Full Professor at the University of Grande Rio (UNIGRANRIO) and Professor at the Postgraduate Program in International Law (Doctorate and Master's) at the State University of Rio de Janeiro (UERJ). Invited Professor of several Institutions of Higher Study in Brazil and abroad. Vice President of the Education Commission of the Brazilian Bar Association - Rio de Janeiro (OAB/RJ - $2019 \mathrm{x}$ 2020) Researched with funding from several development agencies, such as CNPq, CAPES, MJ/PNUD, FAPERJ, FUNADESP and Dom Cintra Foundation. Holder of the research title granted by FAPERJ (Scientist of the State of Rio de Janeiro). In addition to being a lawyer, he also has a degree in Business Administration and has guided his professional practice in the field of Public Law. He is also a legal consultant and expert, having served as Legal Director and Attorney at the Municipal Secretariat for the Environment (Magé-RJ) and Municipal Secretary of Administration (Duque de Caxias-RJ-January 2013 to December 2016). Member of the Brazilian Society of International Law (SBDI); the Brazilian Academy of International Law (ABDI); the Duquecaxiense Academy of Letters and Arts (ADLA); the National Council for Research and Education in Law (CONPEDI); the International Studies Association (ISA); of the Association of Teachers of Environmental Law of Brazil (APRODAB). Editor of INTER - Journal of International Law and Human Rights at UFRJ. Coordinator of the Laboratory of Studies and Advanced Research in International and Environmental Law (LEPADIA) and the Research Group in International Law (GPDI/FND/UFRJ) He is also the author of several books, besides having several articles published in specialized magazines, books in co-authorship, periodicals and annals. E-mail: <sidneyguerra@terra.com.br>.https://orcid.org/0000-0002-5309-662X

*** Master in International Law (LLM) and Master in Latin American Studies from the University of California Los Angeles, EEUU (UCLA), Doctor of Laws from Universidad Pontificia Bolivariana, Colombia (UPB), and Juris Doctor from William \& Mary, Virginia, EEUU. University law professor teaching international law, international business \& transborder criminal law, human trafficking, human rights, anti-corruption, corporate social responsibility, terrorism/global security. Consultant for USAID, US Southern Command, US State Department, United Nations, and law firms. Involved in global anti-corruption and anti-human trafficking training/education, and judicial reform and rule of law initiatives in fragile, transitional, and post-conflict states. Training military commanders in integrating human rights and international humanitarian law protocols and interacting cooperatively with NGO's working in operational zones of conflict. Stetson University College of Law: Gulfport, FL, US - Estados Unidos da América do. E-mail: 〈NAGLE@law.stetson.edu>.
\end{abstract} https://orcid.org/0000-0002-1870-1441 
1 Introduction. 2 The Humanitarian Law Standard and the Human Rights Standard: Convergences and Divergences. 2.1 Military Occupation of Eritrea by Ethiopia. 2.2 Military Occupation of Palestine by Israel. 3 The Dichotomies in the Field in the Complex Relationship of Occupant StateOccupied Population. 3.1 The Military Occupation under International Humanitarian Law. 3.2 The Military Occupation under International Human Rights Law. 4 The Complementarity of Normative Systems when Appropriate and the Necessary Submission of International Humanitarian Law. 5 Concluding Remarks. References.

\section{ABSTRACT}

Objectives: This article aims to revisit the interrelationship between International Humanitarian Law (IHL) and International Human Rights Law (IHRL), in honour of their respective normative scopes and in order to carry out an analysis of their complementary or supplementary application, towards the construction of a more appropriate tool for the protection of human beings in extreme situations, as it occurs during armed conflicts. This is because, amid the multifaceted vulnerabilities that accumulate in today's conflicts, it is essential to provide the most effective source of protection - proportional to the demands for protection that are manifested today, particularly in military occupations around the world, whose occurrence will be the focus of this research.

Methodology: As for the method of approach concerning the logical basis of the investigation, the hypothetical-deductive procedure method was selected, with a qualitative approach, and a bibliographic research and case analysis technique, insofar as the corroboration or falsification of the main hypothesis about the effective complementary and harmonious application of IHRL will be tested to cases of human rights violations in International Armed Conflicts in the military occupation modality. The exploratory aim was developed through the understanding of the Military Occupations as an ideal scenario to indicate the legal antinomies between IHRL and IHL.

Results: In this investigation, specifically utilising the Military Occupations scenario, it was concluded that the most appropriate positions for the protection of the vulnerable should be substantially grounded on IHRL fundamentals regarding the still obscure area of transition between the two areas, aiming at the consolidation of a doctrinal understanding to base new consultative opinions in the future.

Contributions: Given this framework, the core of this work lies in the understanding of the praxis for the complementary application of both aspects in armed conflicts, considering not only International Human Rights Law as lex generalis, but their effective

\footnotetext{
* Master's degree student in International Law at the Rio de Janeiro State University (UERJ). Humanitarian Professional. Member of the Brazilian Red Cross-National Response Team. Volunteer at the Brazilian Red Cross Amazonas. Researcher in International Humanitarian Law and Humanitarian Diplomacy. Universidade do Estado do Rio de Janeiro (UERJ), Rio de Janeiro, RJ, BR. E-mail: <adriasfs@outlook.com>. https://orcid.org/0000-0002-8935-0917
}

33 • R. Opin. Jur., Fortaleza, ano 19, n. 32, p.32-57, set./dez. 2021 
Human rights violations perpetrated by state agents in military occupations: analysis of the incursion of international human rights law to the normative territory of the armed conflicts

overlap to the detriment of International Humanitarian Law, when it is most beneficial to human protection in the cases of Military Occupations.

Keywords: International Human Rights Law. International Humanitarian Law. Military Occupations. Human Rights Violations. Legal Antinomy.

\section{RESUMO}

Objetivos: Este artigo tem como objetivo revisitar a inter-relação entre o Direito Internacional Humanitário (DIH) e o Direito Internacional dos Direitos Humanos (DIDH), em homenagem aos seus respectivos âmbitos normativos e com o objetivo de realizar uma análise de sua aplicação complementar ou suplementar, no sentido da conformação de uma ferramenta mais adequada para a proteção do ser humano em situações extremas, como ocorre durante os conflitos armados. Isto porque, em meio às vulnerabilidades multifacetadas que se acumulam nos conflitos atuais, é imprescindível fornecer a fonte de proteção mais eficaz - proporcional às demandas de proteção que hoje se manifestam, principalmente em ocupações militares em todo o mundo, cuja ocorrência será o foco desta pesquisa.

Metodologia: Quanto ao método de abordagem considerando a base lógica da investigação, selecionou-se o método de procedimento hipotético-dedutivo, com abordagem qualitativa, bem como a técnica de pesquisa bibliográfica e análise de casos concretos, na medida em que a corroboração ou falsificação das principais hipóteses sobre a efetiva aplicação complementar e harmoniosa do DIDH será testada em casos de violações de direitos humanos em Conflitos Armados Internacionais na modalidade Ocupação Militar. O objetivo exploratório foi desenvolvido através da compreensão das Ocupações Militares como um cenário ideal para indicar as antinomias legais entre o DIDH e o DIH.

Resultados: Nesta investigação, utilizando especificamente o cenário das Ocupações Militares, concluiu-se que as posições mais adequadas para a proteção dos vulneráveis deveriam estar substancialmente alicerçadas nos fundamentos do DIDH quanto a ainda obscura área de transição entre as duas vertentes do direito, visando à consolidação de uma compreensão doutrinária a fundamentar novas opiniões consultivas no futuro.

Contribuições: Diante desse quadro, o cerne deste trabalho reside na compreensão da práxis para a aplicação complementar de ambos os aspectos nos conflitos armados, considerando não apenas o Direito Internacional dos Direitos Humanos como lex generalis, mas sua efetiva sobreposição em detrimento do Direito Internacional Humanitário quando é mais benéfico para a proteção humana nos casos de Ocupações Militares.

Palavras-chave: Direito Internacional dos Direitos Humanos. Direito Internacional Humanitário. Ocupações militares. Violação de direitos humanos. Antinomia Legal.

\section{RESUMEN}


Objetivos: Este artículo tiene como objetivo revisar la interrelación entre el Derecho Internacional Humanitario (DIH) y el Derecho Internacional de los Derechos Humanos (DIDH), en honor a sus respectivos ámbitos normativos y con el fin de realizar un análisis de su aplicación complementaria o suplementaria, hacia la construcción de una herramienta más adecuada para la protección de los seres humanos en situaciones extremas, como ocurre durante los conflictos armados. Esto se debe a que, en medio de las multifacéticas vulnerabilidades que se acumulan en los conflictos actuales, es fundamental brindar la fuente de protección más efectiva, proporcional a las demandas de protección que se manifiestan hoy, particularmente en las ocupaciones militares alrededor del mundo, cuya ocurrencia será el enfoque de esta investigación.

Metodología: En cuanto al método de abordaje sobre la base lógica de la investigación, se seleccionó el método del procedimiento hipotético-deductivo, con enfoque cualitativo, y una técnica de investigación bibliográfica y análisis de casos, en cuanto a la corroboración o falsedad de las principales hipótesis sobre la efectividad. Se probará la aplicación complementaria y armoniosa del DIDH a casos de violaciones de derechos humanos en Conflictos Armados Internacionales en la modalidad de ocupación militar. El objetivo exploratorio se desarrolló a partir de la comprensión de las Ocupaciones Militares como escenario ideal para señalar las antinomias legales entre el DIDH y el DIH.

Resultados: En esta investigación, utilizando específicamente el escenario de Ocupaciones Militares, se concluyó que las posiciones más adecuadas para la protección de los vulnerables deben basarse sustancialmente en los fundamentos del DIDH en relación con el área de transición aún oscura entre las dos vertientes del derecho, con el objetivo de la consolidación de un entendimiento doctrinal para sustentar nuevas opiniones consultivas en el futuro.

Contribuciones: Ante este marco, el núcleo de este trabajo radica en la comprensión de la praxis para la aplicación complementaria de ambos aspectos en los conflictos armados, considerando no solo el Derecho Internacional de los Derechos Humanos como lex generalis, sino su efectiva superposición en detrimento del Derecho Internacional Humanitario. cuando es más beneficioso para la protección humana en los casos de Ocupaciones Militares.

Palabras-clave: Derecho Internacional de los Derechos Humanos. Derecho Internacional Humanitario. Ocupaciones militares. Violaciones de derechos humanos. Antinomia legal.

\section{INTRODUCTION}

The close relationship between International Humanitarian Law and International Human Rights Law in the theoretical field gives rise to a series of fundamental convergences to the smooth functioning of international protection of the 
Human rights violations perpetrated by state agents in military occupations: analysis of the incursion of international human rights law to the normative territory of the armed conflicts

human person worldwide. With the primary purpose of protecting in all circumstances, the aforementioned protective legal network seeks, even, to prevent the individual from suffering again, protecting him from suffering through not only repression but also the prevention of the violation of his rights.

In practice, however, the divergences regarding the conflict of rules and principles applicable to specific cases, as well as the interpretation used to resolve such antinomies, sometimes imply disastrous consequences for the protected legal object, the life and the human dignity. In this context, the military occupation emerges as an ideal object of research for this study, since no other reality arising from armed conflicts provokes so many antinomies as the labyrinthine relationship between the need to subdue enemy forces towards the military objective of the conquest - with an emphasis in surrender - and the opposed obligation to protect the population of the occupied state. As a "new government", the Occupying power inherits the duties arising from the newly established vertical relationship with the population of the Occupied State.

To the aforementioned aspects, it is necessary to add what is understood, from the perspective of the present research, as the main problem: how to harmonize the rules of IHRL and IHL - in the normative, consultative and jurisprudential fields - in cases of rights violations human rights perpetrated by representatives of the Occupying State against the population of the occupied state (regardless of resistance) in the International Armed Conflicts (CAI) in the military occupation modality, considering the concrete cases of today?

Furthermore, in the iteration of this problem, the following questions must be faced: if harmonization is not possible because the rules or principles are opposed, which ones should prevail? The analysis on the solution of the antinomy should take place under the rule of which procedure? What are the main human rights violations commonly committed in military occupations? How to differentiate human rights violations and violations of International Humanitarian Law in armed conflicts?

The main intention of this proposal is the search for the improvement of the International Protection of the Human Person. This is because, allowing a supposedly effective rule-since in practice it is deficient, as it creates arbitrariness on the part of the State under the guise of its basic principles -, remains with sovereign jurisdiction, not only creates legal uncertainty but also generates a feeling of harmful illusory protection, especially when present in the core of the protection of the human person.

When analysing the referenced research object, the main focus will be to understand how to harmonize the norms concerning International Human Rights Law and International Humanitarian Law in cases of human rights violations perpetrated by state agents of the Occupying State against the population of the Occupied State, 
regardless of resistance, in the International Armed Conflicts in the military occupation modality, considering the specific cases analysed.

In the first moment, this research aims to know in depth the convergences and divergences that exist between International Humanitarian Law and International Human Rights Law. In the sequence, the next step will deepen the investigation to deal with the human rights violations perpetrated by state agents of the Occupying State (Occupying power) to the citizens of the occupied State (Protecting Power) and the phenomenon of asymmetric conflicts, as well as addressing the specificities of the military occupation modality of the Conflicts International Armed Forces and their relationship with complex border systems.

Bibliographic and documentary research was the methodological procedure adopted and the national and international doctrine in International Human Rights Law and International Humanitarian Law, as well as the conventional legislation concerning the subject, were chosen as sources of data collection. The selection of readings for the bibliographic research was done analytically and the documentary analysis was based on the sources already mentioned. The works consulted for the theoretical construction of this article remain correlated at the end of this preliminary project.

The database used to remove the specific cases was the Rule of Law in Armed Conflicts Project (RULAC) ${ }^{1}$, from the Geneva Academy, a system that aims to monitor armed conflicts in the world. This is because, the incorrect application of the rules of International Humanitarian Law, with defects of existence and validity, generates damages to the entire normative system. Thus, to offer a correct classification of armed conflicts, the applicable rules and the parties involved in the conflict, the RULAC system becomes a normative parameter for researchers in the field of International Humanitarian Law.

\section{THE HUMANITARIAN LAW STANDARD AND THE HUMAN RIGHTS STANDARD: CONVERGENCES AND DIVERGENCES}

The following conjecture will be analysed, and, if the hypothesis is true, the conjecture will also be: can the rules of International Humanitarian Law and International Human Rights Law be applied in complementarity in International Armed Conflicts in the modality of military occupation? How can this be done? Then, the analysis will apply the theory of corroboration and falsification of the following

\footnotetext{
${ }^{1}$ The "Rule of Law in Armed Conflicts Project" is a portal that aims to identify, monitor and classify situations of armed violence in the world and present such data in an accessible format. It is considered globally as a source of legal reference for International Humanitarian Law.
}

37 R. Opin. Jur., Fortaleza, ano 19, n. 32, p.32-57, set./dez. 2021 
Human rights violations perpetrated by state agents in military occupations: analysis of the incursion of international human rights law to the normative territory of the armed conflicts

hypothesis: The rules of IHL and IHRL can be applied in complementarity in International Armed Conflicts in the military occupation modality, and, particularly, in this case, the norms of IHRL overlap the IHL rules, in order to realize the protection and prevention of human rights violations by the Occupying State ${ }^{2}$ (OTTO, 2012) against the population of the Occupied State, re-establishing the parity, at least legal, between the Occupying Power and the Protective Power ${ }^{3}$ (PROVOST, 2004; KALSHOVEN; ZEGVELD, 2001).

The hypothesis raised for a possible solution is that, in fact, the complementarity between both aspects in the factual context of military occupations is possible and indicated, so that the International Protection of the Human Person expands in armed conflicts. This must occur so that, in particular, the IHRL is considered not as a lex generalis (OBERLEITNER, 2015) - therefore, ceasing to be at the mercy of the special legislation -, in addition to acting as a parameter of proportionality and adequacy to the International Humanitarian "Rule of Law" in these cases, and may even prevail in particular situations.

Situations of armed violence can reach certain thresholds of violence and impacts on the community and social order of the territory where it is located. Depending on their extent and intensity, these will or will not be characterized as International Armed Conflict or Non-international Armed Conflict. First, it urges that in cases where IHL rules are not applied, other forms of protection will be used, such as the provisions of International Human Rights Law and the domestic law of the State in question.

Portanto, não se trata de fazer da guerra uma situação humana, e, do mesmo modo, não se pretende que suas regras de caráter humanitário que regem a condução das hostilidades sejam utilizadas pelos beligerantes como um argumento para considerar sua causa como sendo uma guerra justa, mas se propõe a impedir que as partes em um conflito armado atuem com uma crueldade cega e implacável, e proporcionar a proteção fundamental que os mais diretamente afetados pelo conflito necessitam, sem que a guerra de seguir sendo o que sempre foi: um fenômeno aterrador ${ }^{4}$ (GUERRA, 2021, p. 511).

Among the applicable global provisions, it is necessary to highlight the Declaration of Minimum Humanitarian Standards, which determines the minimum

\footnotetext{
2 A term widely used by doctrine to refer to the military occupation Institute in International Humanitarian Law. Taken from Targeted Killings and International Law.

${ }^{3}$ Terms of the doctrine of occupation to designate the Occupying State and the Protecting Power.

${ }^{4}$ Therefore, it is not a question of making war a human situation, and likewise, its humanitarian rules governing the conduct of hostilities are not intended to be used by belligerents as an argument to consider its cause as a just war, but it aims to prevent the parties to an armed conflict from acting with blind and relentless cruelty and to provide the fundamental protection that those most directly affected by the conflict need, without preventing war from continuing to be what it has always been: a terrifying phenomenon (tradução nossa).
} 
humanitarian standards applicable to all situations - including internal disturbances, local tensions, attacks on public order - and to all people - including groups and authorities, regardless of their legal status or any other characteristic aspect - arts. 1 and 2 of Document No. 55, UN, Minimum Humanitarian Standards (UNITED NATIONS, 1990). Furthermore, in the event of an armed conflict, IHL rules will be applied to the entire national territory of the parties involved in the conflict and will not be limited to the battlefield

An International Armed Conflict is nothing more than the traditional conception of war, understood for thousands of years as the doom of humanity, derived from the innate desire for destruction and death. To be classified as such, the CAI must represent the situation of violence in which two or more states resort to armed force. Both the reasons for the conflict and the intensity are not considered for the classification. For International Armed Conflicts, all 1949 Geneva Conventions, Additional Protocol I and customary IHL apply. Besides, the declaration of war by the States Parties is not necessary, and the reality is sufficient. Another important point is that the duration of the conflict or variations in intensity for armed violence, such as massacres, are disregarded.

Furthermore, it is worth emphasizing the understanding that the State was created to serve human beings, in its inherent intention of protection. For the same purpose, there is Law, in its purest form, as a tool to protect human beings from other human beings and to regulate everything that exists; including war. The convergence of the International Humanitarian Law and the International Human Rights Law is understood as an essential legal phenomenon for the effectiveness of the protection of the human being, so as not to allow normative gaps in the isolated areas to determine the destinies of those who need the norm.

Thus, considering the permanent state of bellicosity worldwide, an intrinsic characteristic of the human being, bringing with it serious violations of human rights, there is no more precise moment than this to bring the topic to the discussion. In this case, the State responsible for the protection of the individual's human rights fails to guarantee them through imperative action or omission, imposing or providing opportunities for serious violations of IHL and, consequently, causing other disastrous results under the aegis of International Refugee Law and International Human Rights Law.

It should be noted that International Human Rights Law (despite having developed with clear inclinations to only concern times of peace, while International Humanitarian Law would turn to times of war), has also been applied concerning violations of basic rights and their respective investigations and prosecutions by the State in which the armed conflict develops (MURRAY, 2016). 
Human rights violations perpetrated by state agents in military occupations: analysis of the incursion of international human rights law to the normative territory of the armed conflicts

In other words, the International Human Rights Law was established to protect individuals from violations perpetrated by their State of origin through state agents, representatives of the one power that originates from it, through a vertical relationship of applicability. From this understanding, we can draw some assumptions specific to human rights, such as the idea that the relationship between the State and the individual must be harmonious and beneficial, not only concerning negative obligations but also in supporting the development of the individual potential of those maintained under state jurisdiction (PROVOST, 2004).

Also, International Human Rights Law, despite its unrestricted applicability for circumstances - limits, like International Humanitarian Law, to armed conflicts, or situations of forced displacement, such as International Refugee Law -, is restricted, to a certain extent, to the regional areas of its inspection, monitoring and sanction systems, in addition to the State itself. In contrast, International Humanitarian Law is established through the horizontal dimensioning of its effectiveness, by establishing mutual obligations between states, or even between non-state armed groups concerning humanitarian norms.

In this regard, the theme to be investigated stands out, as it seeks to expose valid solutions to contribute to the doctrinal and jurisprudential debates considering the interference of International Human Rights Law in the area of jurisdiction of International Humanitarian Law, with the simple objective of complementing harmoniously the International Protection of the Human Person. In the still obscure area of transition between the two fields, it is required to consolidate the points of convergence and divergence, so that they are not used for shady purposes.

In this context, some of the main divergences between the law areas are concentrated. As an example, we can mention the use of lethal force, which in IHL appears as the basic principle of the very existence of armed conflict and, consequently, of IHL - as long as necessary for the achievement of military objectives, since the war itself consists of overlapping its military forces to the enemy's forces. On the other hand, that same lethal force, for the IHRL and national systems, is the ultima ratio (BRENNEKE, 2020).

In this respect, it is worth saying that we have adopted the line of complementarity for the maximum possible protection regarding the horrors of war. Besides, it is important to consider the harmony between both aspects and apply the provisions with caution, so that they are effective and positive for the object of protection for which the standard was devised (PROVOST, 2004).

In the sequence, two examples of military occupations currently underway will be presented, in order to analyse the points of convergence between the IHL and the IHRL 
when it comes to violations. A particularly interesting point of convergence between the two areas of International Law is human dignity:

O Direito Internacional Humanitário tem a finalidade de amenizar o sofrimento alheio, buscando, ainda que em uma situação catastrófica e pavorosa, o mínimo que se possa preservar em uma pessoa: a sua dignidade. (...) O princípio da humanidade se apresenta como "coluna vertebral" do $\mathrm{DIH}$, estabelece que em qualquer situação, ainda que degradante, deva-se buscar conservar a dignidade da pessoa humana (GUERRA, 2021, p. 515). ${ }^{5}$

Thus, it is important to emphasize Swinarski's notes (SWINARSKY, 1996, p. 12), regarding the importance of International Humanitarian Law, considered as a "right of war", when determined at the United Nations Conference on Human Rights, in Tehran, in 1968, in the resolution XXIII, the essentiality of protection in times of war, as rules considered as the minimum necessary for the maintenance of dignity.

In addition, respect for peace is "a fundamental condition for full respect for human rights, with war being the denial of that right." Coupland's thought goes in the same direction when proposing that "the predisposition of humans to manufacture and use weapons, humanity and international law go hand in hand as universal needs of human existence" (COUPLAND, 2001, p. 989).

\subsection{MILITARY OCCUPATION OF ERITREA BY ETHIOPIA}

Regarding the Military Occupation of Eritrea by Ethiopia, there is a glimpse of a border conflict, in which the area disputed for decades is the subject of intense armed confrontation. Currently, the occupation covers a thousand kilometres of the territory of Eritrea (KEBEBEW, 2018). For the next table, the reports used were: Eritrea Ethiopia Armed Conflict. (GENEVA ACADEMY), the World Report 2019: events of 2018 (HRW) and the Global Humanitarian Overview 2019 (OCHA).

Frame 1 - Representative table of the studies of the effectiveness of Geneva law concerning persons protected in the Military Occupation of Eritrea by Ethiopia (International Armed Conflict), as well as regarding the IHRL body of laws

\begin{tabular}{|c|c|c|}
\hline \multicolumn{3}{|c|}{ MILITARY OCCUPATION OF ERITREA BY ETHIOPIA } \\
\hline MAIN PROTECTED & MAIN VIOLATIONS TO IHL & MAIN VIOLATIONS TO IHRL \\
PERSONS AFFECTED & & \\
\hline Prisoners of War and & Mistreatment of Political Prisoners; Rape; & Right to Humane Treatment. Torture; \\
\hline
\end{tabular}

\footnotetext{
${ }^{5}$ International Humanitarian Law aims to alleviate the suffering of others, seeking, even in a catastrophic and dreadful situation, the least that can be preserved in a person: dignity. (...) The principle of humanity presents itself as the "vertebral column" of IHL, establishes that in any situation, even if degrading, one must seek to conserve the dignity of the human person (tradução nossa).
}

41 R. Opin. Jur., Fortaleza, ano 19, n. 32, p.32-57, set./dez. 2021 
Human rights violations perpetrated by state agents in military occupations: analysis of the incursion of international human rights law to the normative territory of the armed conflicts

\begin{tabular}{|c|l|l|}
\hline Detainees & $\begin{array}{l}\text { Torture; Lack of Medical Care and Legal } \\
\text { Guarantees; Restriction of access to food; }\end{array}$ & $\begin{array}{l}\text { Cruel, inhuman, or degrading } \\
\text { punishment or treatment; Dignity of } \\
\text { all persons deprived of their liberty; }\end{array}$ \\
\hline Civilians & $\begin{array}{l}\text { Torture; State terrorism; extrajudicial } \\
\text { executions; }\end{array}$ & $\begin{array}{l}\text { Torture; Right to life; No one shall be } \\
\text { arbitrarily deprived of his life; }\end{array}$ \\
\hline $\begin{array}{c}\text { Internally Displaced } \\
\text { Persons and Refugees }\end{array}$ & $\begin{array}{l}\text { Forced displacement (internally displaced } \\
\text { persons); }\end{array}$ & Freedom of movement and residence; \\
\hline
\end{tabular}

\subsection{MILITARY OCCUPATION OF PALESTINE BY ISRAEL}

Concerning the Military Occupation of Palestine by Israel, there is a glimpse of a historic conflict, marked by a political division outside the knowledge of the internal religious conflict between the two peoples, so that Israel occupies the area that had been destined for peaceful coexistence between both (FERRER, 2018). Since then, a series of violence has been perpetrated against the human dignity of Palestinians in the occupied areas (Gaza Strip and the West Bank and East Jerusalem areas). For the next table, the reports were used: The Armed Conflict in Israel-Palestine (GENEVA ACADEMY), the World Report 2019: events of 2018 (HRW) and the Global Humanitarian Overview 2019 (OCHA).

Frame 2 - Representative table of the studies of the effectiveness of Geneva Law concerning persons protected in the Military Occupation of Palestine by Israel (International Armed Conflict), as well as regarding the IHRL body of laws

\begin{tabular}{|c|c|l|}
\hline \multicolumn{4}{|c|}{ MILITARY OCCUPATION OF PALESTINE BY ISRAEL } \\
\hline $\begin{array}{c}\text { MAIN PROTECTED } \\
\text { PERSONS AFFECTED }\end{array}$ & $\begin{array}{c}\text { MAIN VIOLATIONS TO } \\
\text { IHL }\end{array}$ & \multicolumn{1}{c|}{ MAIN VIOLATIONS TO IHRL } \\
\hline $\begin{array}{c}\text { Wounded and Sick in } \\
\text { Land, Naval Forces and } \\
\text { Castaways }\end{array}$ & $\begin{array}{l}\text { Restriction on medical care } \\
\text { and treatment of the wounded; } \\
\text { amputations due to lack of } \\
\text { medical treatment of injuries; }\end{array}$ & $\begin{array}{l}\text { Every person has the right to have his physical, } \\
\text { mental, and moral integrity respected; }\end{array}$ \\
\hline $\begin{array}{c}\text { Prisoners of War and } \\
\text { Detainees }\end{array}$ & $\begin{array}{l}\text { Arbitrary arrest; mistreatment; } \\
\text { Civilians }\end{array}$ & $\begin{array}{l}\text { No one shall be subject to arbitrary arrest or } \\
\text { imprisonment; Right to Humane Treatment. } \\
\text { Cruel, inhuman, or degrading punishment or } \\
\text { treatment; Dignity of all persons deprived of } \\
\text { their liberty; }\end{array}$ \\
\hline \multirow{2}{*}{$\begin{array}{l}\text { Civilians considered as targets; } \\
\text { mistreatment; restriction of } \\
\text { assets essential to their survival; } \\
\text { restriction to electricity, food, } \\
\text { water, education, medical care; } \\
\text { collective punishments; }\end{array}$} & $\begin{array}{l}\text { No one shall be arbitrarily deprived of his life. } \\
\text { Everyone has the right to a standard of living } \\
\text { adequate for the health and well-being of himself } \\
\text { and of his family, including food, clothing, } \\
\text { housing and medical care and necessary social } \\
\text { services; Punishment shall not be extended to } \\
\text { any person other than the criminal. }\end{array}$ \\
\hline
\end{tabular}

Remains valuable to point out the dispositions stated at the Human Rights Council's Report of the high-level fact-finding mission to Beit Hanoun established under Council resolution S-3/1, A/HRC/9/26, in $1^{\text {st }}$ September of 2008: 
Human rights law is also applicable in armed conflict and occupation. The mission considers that this reckless disregard for civilian life also constitutes a violation of the right to life as set out in article 6 of the International Covenant on Civil and Political Rights to which Israel is a party. The right to life includes the negative obligation to respect life and the positive obligation to protect life. The Human Rights Committee has stated that States parties should take measures not only to prevent and punish deprivation by criminal acts but also to prevent arbitrary killing by their own security forces. No exception is made for acts during the war (HUMAN RIGHTS COUNCIL, 2008, p. 16).

Based on the studies presented here, it appears that it is possible to affirm the convergences between both protective systems, insofar as, considering, for each body of laws similar trends of violations are seen, specific to each scenario. Furthermore, it is also perceived that the violations tend to be approached when the recipient subject is the protected person, either when considering categories of vulnerable people - as it was in the early days of the development of the IHRL - or when deriving the idea of minimum rights for all human beings.

Furthermore, the identification of the main violations in each body of laws is one of the first steps for the respective punishments to be determined and, thus, to guarantee a greater level of effectiveness for the norms, through analysis of the antinomies.

\section{THE DICHOTOMIES IN THE FIELD IN THE COMPLEX RELATIONSHIP OF OCCUPANT STATE-OCCUPIED POPULATION}

When International Law goes to the field, particularly considering an armed conflict scenario or, in other words, collapsed Rule of Law scenario, it is sometimes difficult to observe its practical consequences or how this norm will apply itself when it is necessary to invoke it. The truth is that the abstraction and generality of the norm will hardly meet the challenges of practical reality. However, we can observe the following dynamic occurring: legal frameworks, aegis, shields, imaginary normative umbrellas opening up on subjects of law to protect them and upon it, the classification "International Humanitarian Law" or "International Human Rights Law" hangs.

Besides, the study of the present object is particularly interesting, because it contains in itself a wide range of legal antinomies to be solved in the most serious circumstance to human life and dignity: the armed conflict. Such antinomies, if not resolved most appropriately, end up giving rise to serious violations of human rights, using, for the aforementioned shady purposes, the established legal channels. Given the above, we have no choice but to investigate the present demand, with the primary 
Human rights violations perpetrated by state agents in military occupations: analysis of the incursion of international human rights law to the normative territory of the armed conflicts

purpose of preventing the deterioration of the International Protection of the Human Person, avoiding its ruin by its very foundations.

The premise is sustained insofar as it is necessary to balance the legal relationship disproportionately inclined to the desires of the Occupying State when it can be seen such a vulnerability deliberately reserved for the population of the occupied State. As described by Sassòli (2019, p. 303): "Such expanded protection is justified because such civilians are living in their territory and through no choice of their own come into contact with the enemy who gained territorial control over the place where they live."

To any Occupying State is given the obligations and duties, before the Occupied State, regarding the protection of the human rights of the population. At the same time, the mandatory laws of the International Armed Conflict Law govern, regardless of resistance to the occupation (CRAWFORD; PERT, 2015). If there is resistance, conflicts of rules are accentuated, as the Occupying power must simultaneously protect the human rights of the Occupied Population and do what is necessary and sufficient within the principle of the military necessity of IHL - to achieve its military objectives. It is also relevant to highlight that the lack of resistance does not mean consent for any legal means.

Furthermore, it is interesting to note that military occupations, as separate modalities amid IHL, have established a set of rules around these that concern the obligations that the Occupying State has, even after the end of the occupation. This is because the Occupying State takes the place of the occupied state, deriving from it its state obligations and duties towards citizens. Regardless, an Occupying State's duties under International Law include recognition that even while a military occupation is in effect and the exercise of state sovereignty by the Occupied State may be suspended, the Occupied State remains a State under International Law and retains its fundamental rights. Territorial integrity and political independence should be foremost among those rights, as emphasized under Art. 2(4) of the UN Charter (BROWN, 2004).

The mentioned set of rules - Laws of occupation or law of belligerent occupation (SASSÒLI, 2019) - is summarized in art. 6 of the IV Geneva Convention of 1949 and refers: firstly, to respect for the Geneva Conventions and their Protocols and to the protection afforded to protected persons - and in these terms, it is essential to emphasize the responsibility provided for in art. 29 of the IV Geneva Convention of 1949, which deals with the State's responsibility for the actions of its agents against protected persons, an understanding confirmed by the current doctrine (TORROJA, 2017).

Clearly, then, regarding the occupied population, particularly the civilians those who receive the civilian status and related protection by meeting the criteria of 'not participate in hostilities' - require more thorough safeguard norms which demands no liabilities with the counterparty. To maintain their status under IHL as to the 
Occupying Power, civilians are obliged to not violently resist or use any violent means towards the Occupying Armed Forces, even in a liberating willingness. In contradicting this provision, they can be punished by the Occupying Power introduced legislation while not losing their status (ICRC, 2009). As it can be seen, the configuration of the status is located at a personal scope:

The status, rights, and protections of persons outside the conduct of hostilities do not depend on their qualification as civilians but on the precise personal scope of application of the provisions conferring the relevant status, rights, and protections (e.g., Arts 4 GC III, 4 GC IV, 3 GC I-IV, 75 AP I, 4 to 6 AP II) (ICRC, 2009, online).

On the contrary, the Occupying Power must respect the body of Laws of Occupation, which intends to establish that life remains as normal as possible, in respect of the International Human Rights Law governing the vertical relationship of the de facto State over its de facto citizens. Thereby, the local Rule of Law remains efficient ${ }^{6}$, in addition to other typologies of rules related to the conservation of private and public property, prohibition of displacement or deportation of the occupied population, provision of security, hygiene, public health, food and medical supplies (ICRC, 2009).

\subsection{THE MILITARY OCCUPATION UNDER INTERNATIONAL HUMANITARIAN LAW}

To classify a CAI in military occupation, some criteria must be met, as explained by the RULAC system, used as a database for this research. According to this definition, military occupations have become a prominent modality, due to the identification of a series of characteristics present in some International Armed Conflicts, which granted them a different modus operandi from the other existing CAI. The accentuation of its occurrence also determined the importance of deepening in its study, as well as in the improvement of the specific norms of the military occupations - called "Laws of occupation".

The closest description of a concept for the institute is found in art. 42 of the Hague Regulations contained in the Convention IV Respecting the Laws and Customs of War on Land, of 1907, which determines that a territory is considered occupied, that is, the legal existence of the military occupation, under the terms of International Humanitarian Law, occurs when: "it is actually placed under the authority of the hostile army. The occupation extends only to the territory where such authority has been established and can be exercised". In the same sense, the Geneva Conventions affirm,

\footnotetext{
${ }^{6}$ Concerning the art. 43 of the Regulations concerning the Laws and Customs of War on Land.
} 
Human rights violations perpetrated by state agents in military occupations: analysis of the incursion of international human rights law to the normative territory of the armed conflicts

through art. 2 (2), that "The Convention shall also apply to all cases of partial or total occupation of the territory of a High Contracting Party, even if the said occupation meets with no armed resistance." (ICRC, 1949, p. 35).

As for military occupations, these are characterized by being types of international armed conflicts, which fulfil the elements defined as necessary for their existence, particularly when it comes to the notion of effective control, consisting in the coexistence of three elements:

(I) Armed forces of a foreign state are physically present without the consent of the effective local government in place at the time of the invasion. (II) The local sovereign is unable to exercise his authority due to the presence of foreign forces. (III) The occupying forces impose their authority over the territory. Once one of these three criteria is no longer fulfilled, the occupation has ended (GENEVA ACADEMY, 2021, online).

The ICRC has determined that the rules of International Humanitarian Law "become applicable whenever territory comes under the effective control of hostile foreign armed forces, even if the occupation meets no armed resistance and there is no fighting." (ICRC, 2004, online). The ICRC interprets "Control" in two ways:

It could be taken to mean that a situation of occupation exists whenever a party to a conflict exercises some level of authority or control within foreign territory. So, for example, advancing troops could be considered bound by the law of occupation already during the invasion phase of hostilities. This is the approach suggested in the ICRC's Commentary to the Fourth Geneva Convention (1958). An alternative and more restrictive approach would be to say that a situation of occupation exists only once a party to a conflict is in a position to exercise sufficient authority over enemy territory to enable it to discharge all of the duties imposed by the law of occupation. This approach is adopted by a number of military manuals (ICRC, 2004, online).

The Invasion and Occupation institutes must also be differentiated, following this reasoning, seeking to understand when an invasion becomes a de facto occupation, under the terms of the decision given to the "Trial of Wilhelm List and others" case during the Hostages Trial of the Nuremberg Military Court, in 1948. Also, the similarities found and the very lack of clarity regarding the jurisdictional thresholds of each area - IHL and IHRL - have been used as an argument for the reduction of legal protection in armed conflicts (MELZER, 2019).

It is interesting to note how the differentiation between the two institutes makes no difference when it comes to duties at the level of the Occupying State to the Occupied Population under the judgment of International Human Rights Law, as determined by the trial: 
At the outset, we desire to point out that International Law makes no distinction between a lawful and an unlawful occupant in dealing with the respective duties of occupant and population in occupied territory. There is no reciprocal connection between the manner of the military occupation of territory and the rights and duties of the occupant and population to each other after the relationship has indeed been established. Whether the invasion was lawful or criminal is not an important factor in the consideration of this subject (UNITED NATIONS, 1949, p. 59).

This does not mean that all acts perpetrated by the Occupying Power against the Occupied Population or their property would be considered as crimes, nor that all acts undertaken by the Occupied Population against the Occupying power in terms of armed resistance would be considered an act of self-defence.

It is valuable to consider also the fact that, historically, the reposition to the IHL norms concerning International Armed Conflicts of the 'freedom fighters' from national liberation movements, or, in other words, the peoples which "are fighting against colonial domination and alien occupation and against racist regimes in the exercise of their right of self-determination" (art. 1(4) of Protocol I), as enshrined in the Charter of the United Nations, has improved their protection and dignity safeguard, regarding this remarkably threatened category of person, as they can receive the POW status (SASSÒLI, 2019).

However, there are norms of conduct by the Occupying Power that must be observed under International Law. Another essential point of the discussion presented here is: which court would be competent in these cases to try these crimes, considering the deliberate rejection of a national court recently implemented by the Occupying power to judge itself in its war crimes. At what point, these cases go from being a matter of International Humanitarian Law to becoming a matter of International Human Rights Law and how to ensure that human protection is not threatened, regarding the collision with martial law?

Under International Law, any State can enforce International Humanitarian Law through their national legal systems and their mechanisms. The UN Security Council has the authority as well to take any measures necessary to enforce International Humanitarian Law, including compelling States to comply with their obligations and duties to establish tribunals to investigate violations (ICRC, 2016).

\subsection{THE MILITARY OCCUPATION UNDER INTERNATIONAL HUMAN RIGHTS LAW}

A "Military Occupation" can be described as "a transitional period following the invasion and preceding the agreement on the cessation of the hostilities", as defined in the case law in case No. IT-98-34-T Prosecutor v. Naletilic' et al. (DARCY, 2014) and it 
Human rights violations perpetrated by state agents in military occupations: analysis of the incursion of international human rights law to the normative territory of the armed conflicts

is the factual situation that most closely approximates the aspects of IHL and IHRL. Thus, it can be said that the Occupying power, by taking part or all of the territory of the protective power, replaces the government previously established by its new state. Article 42 of the 1907 Hague Regulations states: "Territory is considered occupied under International Law when it is actually placed under the authority of the hostile army," and that occupation "extends only to the territory where such authority has been established and can be exercised."

In this regard, Additional Protocol I, on the protection of the civilian population in International Armed Conflicts, of which military occupation is a modality, demonstrates the connection to the Human Rights when providing in article 72 (Field of application):

The provisions of this Section are additional to the rules concerning humanitarian protection of civilians and civilian objects in the power of a Party to the conflict contained in the Fourth Convention, particularly Parts I and III thereof, as well as to other applicable rules of International Law relating to the protection of fundamental human rights during international armed conflict (ICRC, 1977, p. 279).

However, in cases of intervention by one State in another through military occupation, it is expected that the same principles that underpin human rights will be respected concerning the citizens of the occupied territory (OTTO, 2012). Considerable effort must be undertaken by the Occupying State to articulate the rule of law in the context of conducting military operations and post-operation while preserving human rights as principles that:

Include the application of the Charter of the United Nations, International Humanitarian Law, human rights law, military law, criminal law and procedure, and constitutional law; Incorporate principles that govern civil and criminal accountability for management and conduct of military operations and post-military operations; Include standards by which national institutions of the Occupied State may be held accountable for their failure to comply with universal legal principles and rules during conflict and post-conflict; Form a framework that governs the emerging relationship between military forces and the civil society and becomes the basis upon which all parties in the conflict and non-combatants will be held accountable for their actions prior to, during, and following military operations and occupation (U. S. ARMY PEACEKEEPING AND STABILITY OPERATIONS, 2004 apud NAGLE, 2008, p. 41).

Additionally, it is relevant to point out the responsibility of the commanding general in the Occupied Territory "to maintain peace and order, punish crime and protect lives and property" (UNITED NATIONS, 1949, p. 69) not only of the occupied inhabitants but also of the occupying troops located in the territory of interest. 
Thus, the strictly territorial interpretation, within the geographic limits of the State, must be extended beyond the jurisdiction initially provided for, so that the State is responsible for violations committed beyond its borders, including to minorities and people of other nationalities (MARTIN et al., 2006).

Furthermore, changes to government institutions introduced in the State occupied by the Occupying State cannot lead to violations of the rights provided for in the IHL and the IHRL, as well as forced transfers and deportations between the territories of the Occupying State and the occupied State are prohibited. As for enlistment, the population of the occupied state cannot be forcibly recruited to compose the military and police forces of the Occupying State, and all the work performed by the population of the occupied state to the Occupying State must receive the counterparts and rights inherent in decent work.

Taking into account the same reasoning, assets and properties of the occupied state cannot be destroyed by the Occupying State, unless such destruction is essential for military operations. Provisions concerning the collective relief of basic needs are also included as part of the protection against violations of human rights and IHL provided for in the IV Geneva Convention of 1949.

Military operations by organized government forces are constrained under International Law and International Humanitarian Law to preserve civilian life to the extent possible in armed conflict and to stabilize the civil society once hostilities have subsided. Many years ago, the United States military, for example, devoted significant study to achieving a balance between prosecuting military operations while respecting human rights, protecting non-combatants, and preserving the rule of law.

Several key factors emerged from the analysis and have direct application to regions of the world where nation-states are engaged in military conflict and struggling to fortify the rule of law, achieve socio-political stability, and respond to violations of human rights as a consequence of belligerent actions. These include:

Recognition that preserving human rights is central to achieving any success during armed conflict. This involves moving away from the rhetoric of human rights to the implementation of human rights. "Without human rights as an integral part of any transition plan in a post-conflict stage, we are failing to establish a sound government." A strategy for communication and consultation with "stakeholders," those at the regional and local level who represent pillars of civil society-lawyers, jurists, doctors, or other key actors such as community and faith-based leaders. "These Communications must be meaningful, genuine and occur before the implementation of the reform measures; not after." Balancing expectations between military/security forces and the stakeholders. There must be realistic expectations about what can be accomplished within a reasonable time frame. Strengthening communications between military/security forces and human rights organizations operating in conflict zones. While a military command may believe that relations with 
Human rights violations perpetrated by state agents in military occupations: analysis of the incursion of international human rights law to the normative territory of the armed conflicts

humanitarian organizations are strong, effort must be undertaken to build partnerships with human rights organizations. "It is critical for the military to be able to identify and inform the respective human rights organizations when there are violations of human rights. The military must be able to assist in being an active player in advancing human rights and rule of law." Improve coordination among all actors involved in legal reform efforts. "The military must expand that effort to all 'actors' such as policymakers, civil society, etc." Establish, fortify, or reform a national constitution and other legal instruments critical to nation-building and preserving human rights. Legal reforms and law-making "must be viewed by all as legitimate, realistic and genuine, both by the international community and the public at large. Without these key components, a legitimate process will not exist. Establish Human Rights Institutions within governments that are funded and capable of carrying out effective investigations and bringing human rights violators to justice (U. S. ARMY PEACEKEEPING AND STABILITY OPERATIONS, 2004 apud NAGLE, 2008, p. 34).

\section{THE COMPLEMENTARITY OF NORMATIVE SYSTEMS WHEN APPROPRIATE AND THE NECESSARY SUBMISSION OF INTERNATIONAL HUMANITARIAN LAW}

Therefore, some considerations about International Humanitarian Law and the protection of human beings are notorious, given their nature peculiar to other aspects of law in general, but common to the aspects of international protection of the human person. Hence its systematic location with International Refugee Law and International Human Rights Law. IHL, as already seen, has a series of qualities, objectives and principles of its own, which must be understood, using systematic interpretation.

IHL would be certainly of no use to join the other fields in a single classification, as the integrationist doctrine raises, or to isolate itself from the other protection nuclei, as the separatist doctrine puts it, and its fundamentally different foundations must also be respected, with its own principles and diverse objectives, the ideal should remain its mutual complementation at the same time that its independence flourishes in the normative and jurisprudential field, as stated by the theory built by Cançado Trindade.

We must also understand that in the collision of principles or norms of the two law areas, context by context and norm by norm must be analysed, that is, in a specific case, one normative system cannot be superimposed on another, as they complement each other, in insofar as they derive from the same original value, which is the protection of human beings in their basic considerations of humanity or reasons of humanity (COOPER; LARSEN; NYSTUEN, 2013).

Thus, a norm or principle is considered to be more appropriate to that context and for this reason, it must be applied at that specific moment and in that situation, or even, a simultaneous application can be recognized. This is particularly true for cases not provided for in treaties, or in the customs of International Humanitarian Law, when it 
is necessary to resort to the Martens Clause as stated in article 1(4) of the Additional Protocol I to the Geneva Conventions.

According to Melzer (2019), we have found fallacious arguments when the normative encounter of the provisions concerning the two areas occurs, with respect to expanding the limits for the use of violence, using IHL and its principle of military necessity - abandoning again, the principle of humanity - while provisions of the Human Rights Act are aimed at prisoners, derogating from their rights, insofar as this is possible for this aspect, while the prisoner of war institute is ignored. This type of dangerous antinomy can be found while provisions of the International Human Rights Law are aimed at imprisoned combatants, derogating from their rights, insofar as this is possible for this aspect, while the prisoner of war status is ignored.

35. International human rights law applies at all times to all peoples during all occasions, including during armed conflict and military occupation. Notwithstanding their distinct purposes, international human rights law is to be read as being complementary to international humanitarian law in situations of occupation, thereby satisfying the purpose of both of these bodies of law to provide broad protection of rights to everyone, including to protected peoples under occupation. 36. As such, the full panoply of social, economic, cultural, political and civil rights enshrined in international human rights law is available to peoples living under occupation to protect their sovereignty over their natural wealth (HUMAN RIGHTS COUNCIL, 2019, online).

In this respect, the applicability or inapplicability of IHRL rules in contexts of armed conflict is no longer discussed, however, a series of doubts arise as to how this application will take place. Another point that we must point out concerns the greater sanctioning force of the IHRL when compared to it by the IHL, spreads through a series of jurisdictional bodies that can be called upon, as well as its advisory force. Finally, it should be noted that International Humanitarian Law is also sometimes referred to in the doctrine "International Law for Human Rights in Armed Conflict" (FORSYTHE, 2012, p. 57) - demonstrating the borderline interrelationship between both.

\section{CONCLUDING REMARKS}

The compartmentalization of the International Protection of the Human Person was historically carried out naturally, considering that the Law when restricted to a social group or a certain condition or state of the human being is born to fulfil a certain need presented by humanity itself, is entitled to specific protection, since the list of people's rights provided for all without distinction is not enough to cover that situation.

As a result of this spontaneous appearance, the other theoretical consequences follow - normative (born in its own time and respecting its historical development and 
Human rights violations perpetrated by state agents in military occupations: analysis of the incursion of international human rights law to the normative territory of the armed conflicts

the set of international legislation), principiological (considering the most important foundations to be protected by the body responsible for propagating it) - and practices, characterized by the performance of the humanitarian protective organization, whatever its nature (independent, autonomous or linked), with a focus on the propagation of humanitarian principles and the dissemination of the duty to comply with humanitarian standards.

Understanding the complex relationship established between the Occupying State and the Occupied Population, as well as the various violations that could occur in an international armed conflict in the military occupation modality demonstrate the variations that the protective systems can produce and how, in practice, it is possible to improve them so that all those in need remain under the necessary legal framework of human rights and humanitarian norms.

To analyse the foundations of International Law is to study the very history of the modern world being built. Besides, the pillars of history, reason and the State intersect perfectly in this theme, considering, even, the border demands. Finally, it is understood the perfect synchrony and adherence of the present study to the line of research and the area of study due to its thematic relevance and systematic fit in the foundations of modern International Law.

Thus, clearly, human rights violations can occur in armed conflicts and not just violations of IHL - or so-called war crimes - as it was intended to demonstrate in the course of this research. For that, it is necessary, however, that the interpretation should always be carried out in a teleological way - considering the purpose for which the protection aspect was created - and systematic - considering the principles and other rules that radiate and conform to the normative body.

Although both areas of law are part of the international protection of the human person and this is its main objective, International Humanitarian Law was initially created to contain the aggressive and commonly disastrous attitudes of states, while International Human Rights Law was created under the foundation of the subjective rights of the human being. IHL was created to lessen the damage to humanity's desire for self-destruction in the form of political abstractions supposedly superior and more valuable to the lives of the people who created this legal fiction, whereas the IHRL was created on the grounds that human life and dignity are more valuable than any fiction. With this brief resumption of origins and foundations, we can understand that the objectives for which each body of law was created determine to a large extent which one should prevail.

Last but not least, International Humanitarian Law cannot be judged for its inability to prevent the occurrence of armed conflicts or military occupations, as this is not its function. Even if armed conflicts did not exist and did not cause as much human 
suffering as they do, IHL itself would not exist. Therefore, the reason for the IHL to exist lies in the endurance of armed conflicts and its consequent devoir to mitigate pain and destruction.

And ergo IHL exists, intrinsically linked to such a raison d'être, precisely because it urges to respect and protect human beings, including their nature. IHL exists to protect us from ourselves and in entire accordance with our twofold nature. To the same extent that humanitarian norms protect people from the consequences of wars, it does not prevent them from occurring, as it is simply not their function. If one day, armed conflicts finally come to an end and become possible to live for peace, IHL would also die, as it will become useless. Conclusively, then, International Human Rights Law could assume its plenitude.

\section{REFERENCES}

BRENNEKE, M. Lethal Autonomous Weapon Systems and Their Compatibility with International Humanitarian Law: a primer on the debate. In: GEIß, R.; GILL, T. D.; KRIEGER, H.; PAULUSSEN, C. Yearbook of International Humanitarian Law 2018. Hague: T.M.C. Asser Press, 2020.

BROWN, B. S. Intervention, self-determination, democracy and the residual responsibilities of the occupying power in Iraq. DAVIS J. INT'L L. \& POL'Y, p. 38-39, 2004.

COOPER, C. G. G.; LARSEN, K. M.; NYSTUEN, G. Searching for a 'Principle of Humanity' in International Humanitarian Law. Cambridge: Cambridge University Press, 2013.

COUPLAND, R. Humanity: what is it and how it influences international law? International Review of the Red Cross, v. 83, n. 844, p. 969-990, 2001.

CRAWFORD, E; PERT, A. International Humanitarian Law. Cambridge: Cambridge University Press, 2015.

DARCY, S. Judges, Law and War: the judicial development of International Humanitarian Law. Cambridge: Cambridge University Press, 2014.

FERRER, M. The Armed Conflict In Israel-Palestine. The War Report 2017. Geneva: Geneva Academy, 2018.

FORSYTHE, D. P. Human Rights in International Relations. New York: Cambridge University Press, 2012. 
GENEVA ACADEMY OF INTERNATIONAL HUMANITARIAN LAW AND HUMAN RIGHTS (GENEVA ACADEMY). Rule of Law in Armed Conflicts Project (RULAC). Geneva: Geneva Academy of International Humanitarian Law and Human Rights. Available at: http://www.rulac.org/. Access in: 10 Apr. 2021.

GUERRA, S.; PRONER, C. Direito internacional humanitário e a proteção internacional do indivíduo. Porto Alegre: Sergio Antonio Fabris, 2008.

GUERRA, S. Curso de Direitos Humanos. 6. ed. São Paulo: Saraiva Educação, 2020.

GUERRA, S. Curso de Direito Internacional Público. 13 ed. São Paulo: Saraiva Educação, 2021.

HAGUE CONVENTION, 4., 1907, The Hague. Proceedings [...]. Regulations concerning the laws and customs of war on land. The Hague, 1907.

HUMAN RIGHTS WATCH (HRW). World Report 2019: events of 2018. 2019. Available at: https://www.hrw.org/world-report/2019 Access in: 2 Jan. 2020.

HUMAN RIGHTS COUNCIL. Report of the high-level fact-finding mission to Beit Hanoun established under Council resolution S-3/1, A/HRC/9/26. [S.l.: s.n.], 2008.

HUMAN RIGHTS COUNCIL. Human rights situation in Palestine and other occupied Arab territories A/HRC/40/73. [S.l.: s.n.], 2019. Available at: https://www.ohchr.org/EN/pages/home.aspx. Access in: 20 Apr. 2021.

INTERNATIONAL COMMITTEE OF THE RED CROSS (ICRC). The Geneva Conventions of 12 August 1949. Geneva: ICRC, 1949. Available at: https://www.icrc.org/en/doc/assets/files/publications/icrc-002-0173.pdf. Access in: 10 Apr. 2021.

INTERNATIONAL COMMITTEE OF THE RED CROSS (ICRC). Protocol Additional to the Geneva Conventions of 12 august 1949, and relating to the protection of victims of international armed conflicts (Protocol I), of 8 June 1977. Geneva: ICRC, 1977.

INTERNATIONAL COMMITTEE OF THE RED CROSS (ICRC). Occupation and International Humanitarian Law: questions and answers. ICRC, 2004. Available at: https://www.icrc.org/en/doc/resources/documents/misc/634kfc.htm Access in: 10 Apr. 2021.

INTERNATIONAL COMMITTEE OF THE RED CROSS (ICRC). Interpretive Guidance on the Notion of Direct Participation in Hostilities under International 
Humanitarian Law. Geneva: ICRC, 2009. Available at: http://www.icrc.org. Access in: 10 Apr. 2021.

INTERNATIONAL COMMITTEE OF THE RED CROSS (ICRC). Frequently Asked Questions on the Rules of War. ICRC, 2016. Available at: https://www.icrc.org/en/document/ihl-rules-of-war-FAQ-Geneva-Conventions Access in: 10 Apr. 2021.

KALSHOVEN, F.; ZEGVELD, L. Constraints of the waging of war: na introduction to International Humanitarian Law. Geneva: International Committee of the Red Cross, 2001.

KEBEBEW, T. The Eritrea-Ethiopia Armed Conflict. The War Report 2018, Genebra, 2018.

MARTIN, F. F. et al. International Human Rights \& Humanitarian Law: treaties, cases \& analysis. New York: Cambridge University Press, 2006.

MELZER, N. International Humanitarian Law: a comprehensive introduction. Geneva: International Committee of the Red Cross, 2019.

MURRAY, D. Practitioners' guide to Human Rights Law in Armed Conflict. Oxford: Oxford University Press, The Royal Institute of International Affairs, 2016.

NAGLE, L. E. On Armed Conflict, Human Rights, and Preserving the Rule of Law in Latin America, Penn St. Int'l L. Rev., v. 27, n. 1, p. 1-44, 2008.

OBERLEITNER, G. Human Rights in Armed Conflict: law, practice, policy. Cambridge: Cambridge University Press, 2015.

OTTO, R. Targeted Killings and International Law. Heidelberg: Springer, 2012.

POPPER, K. R. A lógica da pesquisa científica. São Paulo: Cultrix, 1972.

PROVOST, R. International Human Rights and Humanitarian Law. Cambridge: Cambridge University Press, 2004.

SASSÒLI, M. International Humanitarian Law: rules, controversies, and solutions to problems arising in warfare. Cheltenham: Edward Elgar Publishing Limited, 2019.

SWINARSKY, C. Introdução ao Direito Internacional Humanitário. Brasília: Comitê Internacional da Cruz Vermelha/Instituto Interamericano de Direitos Humanos, 1996. 
Human rights violations perpetrated by state agents in military occupations: analysis of the incursion of international human rights law to the normative territory of the armed conflicts

SWINARSKI, C. O direito internacional humanitário como sistema de proteção internacional da pessoa humana. São Paulo: [s.n.], 2001.

TORROJA, H. Public International Law and Human Rights Violations by Private Military and Security Companies. Cham: Springer International Publishing, 2017.

UNITED NATIONS. The United Nations War Crimes Commission. Law reports of trials of war criminals, v. 8, p. 34-76, 1949.

UNITED NATIONS. UN Doc. E/CN.4/Sub.2/1991/55. 1990. Available at: http://www.un.org. Access in: 20 Apr. 2021.

UNITED NATIONS. International Legal Protection of Human Rights in Armed Conflict. 2011. HR/PUB/11/01. Available at: https://www.refworld.org/docid/4ee9f8782.html. Access in: 5 Jan. 2020.

UNITED NATIONS OFFICE FOR THE COORDINATION OF HUMANITARIAN AFFAIRS (OCHA). Global Humanitarian Overview 2019. 2019. Available at: https://www.unocha.org/global-humanitarian-overview-2019. Access in: 3 Jan. 2020.

\section{NOTE}

The aforementioned article entitled "HUMAN RIGHTS VIOLATIONS PERPETRATED BY STATE AGENTS IN MILITARY OCCUPATIONS: ANALYSIS OF THE INCURSION OF INTERNATIONAL HUMAN RIGHTS LAW TO THE NORMATIVE TERRITORY OF THE ARMED CONFLICTS", represents a direct result of the research developed collectively by the authors, as each one of them delivered contributions, as it can be seen: 1) Author Prof Dr Sidney Cesar Silva Guerra: developed all the theoretical framework about the International Human Rights Law regarding his books and studies specialised on the subject, including the concluding remarks on IHRL; 2) Author Prof Dr Luz E. Nagle: performed the analysis of the International Humanitarian Law theoretical framework on the legal nature of military occupations, in addition to a textual review of the theoretical part of the consequences of the relation Occupant Power-Occupied Population, initially written by her co-author Ádria Fabricio; 3) Author Ádria Saviano Fabricio da Silva brought the first ideas to outline the article, from the concrete cases of Ethiopia and Israel, by comparing the human rights and humanitarian violations from violations analysis reports and then analysing the legal antinomies of the relation Occupant Power-Occupied Population. After initial discussions, all the authors identified that the Military Occupations could be the best example to outline the convergences and divergences of International Human Rights Law and International Humanitarian Law, as it would be possible to, in a constructive way, without aiming at exhausting the topic at all, investigate the exposed scenario as an ideal legal model of antinomies, through the scenario construction 
technique. Afterwards, Author Luz E. Nagle considered that it was essential to add more fundamental concepts regarding military occupations, as further explanations in its confirming elements and Author Sidney Guerra and Author Ádria Fabricio agreed. In the same vein, Author Ádria Fabricio suggested that it was possible to declare, in terms of consistency and a teleological approach, the International Human Rights Law substantially more accurate to protect the individuals in the presented context despite the fact it was not possible to point out that an area of Law could somehow subdue another. Finally, in order to establish closure to the global legal antinomy presented in the research, Author Sidney Guerra added decisive Human Rights Law content and the concluding remarks.

\section{Como citar este documento:}

GUERRA, Sidney Cesar Silva; NAGLE, Luz E.; SILVA, Ádria Saviano Fabricio da. Human rights violations perpetrated by state agents in military occupations: analysis of the incursion of international human rights law to the normative territory of the armed conflicts . Revista Opinião Jurídica, Fortaleza, v. 19, n. 32, p. 32-57, set./dez. 2021. 